\title{
Study on the Influential Factors of CSR in Internet Media under COVID-19
}

\author{
Maohua $\mathrm{Li}^{1}$ \\ ${ }^{1}$ Institute for Corporate Social Responsibility, Xi'an Siyuan University, Xi'an, China \\ *Corresponding author.Email: maohua.li@qq.com
}

\begin{abstract}
The implementation of corporate social responsibility (CSR) needs a series of policy support. This paper systematically combs the specific policies of social responsibility under major emergencies, such as COVID19, and studies the main factors affecting corporate social responsibility in internet media. These factors include historical factors, international factors, evaluation factors, and market factors. The study of this paper provides a reference for enterprises to fulfill their social responsibility under COVID-19.
\end{abstract}

Keywords: social responsibility, influential factors, internet media, COVID-19

\section{INTRODUCTION}

With the rapid development of the internet industry, internet media has become another important medium besides newspapers, radio, and television. At the same time, the social responsibility of internet media has also attracted the attention of experts, scholars, and relevant media employees [1-2]. The COVID-19 has been raging around the world since the end of 2019, and internet media has reported a lot. By focusing on the media performance in this major public health event, we may be able to fully understand the important responsibility of the media in the reporting of social events. Based on the situations above, this paper comprehensively studies the actual situation of major emergencies and discusses the influential factors of CSR in internet media under COVID-19 from the following four aspects.

\section{LITERATURE REVIEW}

In 1923, the British scholar Oliver Sheldon first raised the issue of "social responsibility of management" in the philosophy of management, which laid the foundation of modern management philosophy and emphasized the responsibility of management to workers. Guo Lin (2019) studied the reconstruction of media social responsibility in the context of commercialization and systematically sorted out the connotation of media social responsibility in the new era [3-6]. Huang Jun et al. (2016) studied the implementation of social responsibility strategy and the reconstruction of corporate social responsibility under food safety incidents. Based on the internal and external factors of corporate social responsibility, Li Ming and Guan Wei (2020) put forward internal and external governance mechanism models, such as the stakeholder governance model, discretionary decision-making governance model.
Huang Jun and Li Rui (2019), taking Sina Weibo as the sample, explored the relationship between the coverage of corporate social responsibility by online media and public cognition. Yin Ziran (2009) studied the economic benefits behind the internet media and the internet media literacy in China and then studied the lack of social responsibility of the internet media in China.

\section{THE PHYLOGENY OF CSR ACTIVITY}

From 2000, the beginning of this century, many environmental problems happened in China, and some of them are becoming more and more serious, such as foggy haze. People began to worry about their living surroundings and life quality, so they began to push companies and government to take care of public interests. As more and more people ask their environmental interests from companies and the government. The Chinese government made laws and regulations to regulate companies' activities, such as "the environment protection law of the people's republic of china". Therefore, companies began to care about corporate social responsibility.

And then, many food safety problems happened in China, such as the fake milk problem in 2003, melamine issue in 2008. All these pushed the Chinese government to make laws to regulate companies to take social responsibilities.

Here, This paper uses three words to give a general answer to reasons for the quick development of CSR in China, and they are "regulate", "push" and "understand".

Nowadays, the Chinese government has made several regulations to regulate CSR activities by the internet media companies in China, such as "Social Responsibility Guidelines" in 2005 [7]. And as more and more public and environmental problems happening in China, the Chinese government will make more regulations and other institutions about the implementation of CSR to ensure 
sustainable development. This is the first word "regulate" this paper uses to explain the quick development.

With the development of the Chinese economy, the employee and other stakeholder will care more and more about their interests, such as the environment, food, and they will require and take more and more actions to protect their interests. All the requirements and actions by employee and other stakeholder will "push" internet media company to fulfil the reasons for quick development. This is "push".

As more regulations are made by the Chinese government and used in the stock market, more and more investors will invest their capital more rationally. And there is a positive relationship between financing and CSR, which means the internet media companies taking more CSR will give a sustainable investing return to capital market investors. Therefore, CSR financing will be more important for internet media companies, and if one internet media company wants to attract more investment in the capital

Table 1 The difference and similarity of CSR policy market, it should care more about CSR. The consideration from the capital market and investors on CSR when they are considering an investment is also the word "push". However, for internet media companies, this will help them to understand the importance of CSR better. This is "understand".

\section{THE DIFFERENCE AND SIMILARITY OF CHINESE AND EUROPEAN CSR POLICY}

There are many differences and similarities among Chinese, European, and Hungarian CSR policies. All these differences and similarities cover policymaker, policy purpose, and policy area. To make them clearer, This article summarizes them in the following table 1 .

\begin{tabular}{|c|c|c|}
\hline & Difference & Similarity \\
\hline Policymaker & $\begin{array}{l}\text { European: Government, Central European Bank, } \\
\text { Hungary: Government, Central bank of Hungary } \\
\text { China: Government }\end{array}$ & Government \\
\hline Policy purpose & $\begin{array}{l}\text { European: to cover social public interest and } \\
\text { sustainable development. } \\
\text { Hungary: corporate philanthropy, community } \\
\text { volunteering, and other public issues } \\
\text { China: environmental and food problems, employee } \\
\text { interests }\end{array}$ & $\begin{array}{l}\text { To push companies to care for more } \\
\text { public interests. } \\
\text { To push companies to take more social } \\
\text { responsibilities. } \\
\text { To maintain a sustainable development }\end{array}$ \\
\hline Policy area & $\begin{array}{l}\text { European: listed companies, NGOs, SMEs, etc. } \\
\text { Hungary: listed companies, banks } \\
\text { China: listed companies, financial institutions }\end{array}$ & Listed companies \\
\hline
\end{tabular}

\section{THE EVALUATION OF CSR}

Nowadays, there are several companies in the world to evaluate CSR of internet media companies, and these companies are focusing on the activities taken by the internet media companies. As we know, the activities of internet media companies are very significant to fulfil CSR. However, the CSR information is also important to evaluate the CSR of internet media companies. So the final evaluation framework should be like the following formula.

CSRS $=$ AS $\times$ IDS $\quad$ Formula 1

CSRS: Corporate social responsibility score
AS: Activity score

IDS: Information disclosure score

From the formula above, the corporate social responsibility score should contain two parts: the activity score and information disclosure score. The activity score used in this part is from the Chinese company (http://www.rksratings.com/). And the evaluation of information disclosure (SRID) of internet media companies will be studied further.

Maohua Li (2016) establishes the SRID evaluation framework of agricultural enterprises through the method of the oral theme encoding technology, the frequency analysis, the reliability test, and so on. And the expert opinion method, exploratory factor analysis, and 
confirmatory factor analysis are used to verify the evaluation framework. According to Maohua Li (2016), the SRID evaluation framework of agricultural enterprises consists of four elements and 12 specific indicators. Details are shown in the bellowing table1:

Table 2 SRID evaluation framework

\begin{tabular}{|c|c|c|}
\hline First-Level & Second-Level & Third-Level \\
\hline \multirow{12}{*}{$\begin{array}{c}\text { SRID } \\
\text { Evaluation } \\
\text { Framework } \\
\text { A }\end{array}$} & \multirow{3}{*}{ Content quality B1 } & Objectivity C11 \\
\hline & & Correctness C12 \\
\hline & & Credibility C13 \\
\hline & \multirow{3}{*}{ Total quality B2 } & Relevance C21 \\
\hline & & Completeness C22 \\
\hline & & Sufficiency C23 \\
\hline & \multirow{3}{*}{ Expression quality B3 } & Definition C31 \\
\hline & & Intelligibility C32 \\
\hline & & Conciseness C33 \\
\hline & \multirow{3}{*}{ Effectiveness quality B4 } & Timeliness C41 \\
\hline & & Adaptability C42 \\
\hline & & Testability C43 \\
\hline
\end{tabular}

\section{THE RELATIONSHIP BETWEEN CSR AND MARKET INTEREST}

When the market interest rate is lower, it means the supply of capital is more than the demand for capital. To get more return on capital, investors will care more about the shortterm capital return than sustainable development. And for internet media companies, if the supply of capital in the capital market is more, they will consider less on CSR and choose debt financing. At this time, the capital market initiative is seized by internet media companies, and investors will have fewer and fewer rights of speech in the capital market. To get more financial performance and to use financial leverage, internet media companies prefer to use debt financing, and CSR programs will play a relatively weak role in the capital market and have no right of speech.

When the capital interest rate is higher, it means that the supply of capital in the capital market is less than the demand. During this situation, the capital market initiative is seized by investors in the capital market, and the investors will have more rights of speech in the capital market. Therefore, when investors consider any investment of capital, they will consider more about sustainable development and return, and they will ask internet media companies to take more CSR. To get enough capital, internet media companies will consider more about CSR when financing, which is called CSR financing. Therefore. CSR programs will play an essential role in the capital market when the capital interest rate is higher.

\section{CONCLUSION}

This paper can provide a decision-making reference for emergency management and provide a complete theoretical recognition system for the social responsibility of each department, organization, and individual in the field of emergency and media. Besides, the research perspective and research field of this paper can provide certain research value for scholars in the field of emergency and social responsibility.

The research results of this paper can help create a better internet media environment, improve the social responsibility of internet media, enhance the image of internet media, provide a reference for government departments to formulate more reasonable local management policies of internet media and promote the development of internet media and the implementation of relevant strategies. 


\section{ACKNOWLEDGMENT}

This work is sponsored by the research project of Shaanxi Social Science Fund: "Research on the Social Responsibility of Shaanxi internet media under Major Emergencies", Project No.: 2020R040

\section{REFERENCES}

[1] Sheldon Oliver. The philosophy of management[M]. Pitman, 1924.

[2] Guo Lin.Reconstruction of media social responsibility under the background of commercialization[J]. Journal of Shangqiu Vocational and Technical College,2019,18(05):38-40.

[3] Huang Jun, Jiang Wen, An Hongwen, Jia Yu. Tracking research on food safety incidents and corporate social responsibility system reconstruction of Snow Brand Milk Products Co., Ltd.[J]. Science and Technology of Food Industry,2016,37(09):291-295.

[4] Li Ming, Guan Wei. Research on risk governance mechanism of corporate social responsibility[J].

Industrial \& Science Tribune,2020,19(02):208-210.

[5] Huang Jun, Li Rui. Agenda setting effect of internet media in corporate social responsibility: an experimental study based on the Sina Weibo platform[J]. Modernization of Management, 2019, 39(02):67-70.

[6] Yin Ziran. Study on the social responsibility of internet media from the perspective of "rectifying the vulgar trend of the Internet" [J]. Journalism and Mass Communication Monthly,2009(02):114-115+142.

[7] Maohua Li, Zéman Zeman. Study on the SRID Evaluation Framework of Agricultural Enterprises in China. Visegrad Journal on Bioeconomy and Sustainable Development, 2016, 5(1): 36-40. 